\title{
Scientists wary of weapons research agency
}

Washington

Concern is growing at the US Department of Energy's laboratories that the planned creation of an agency to run their nuclear weapons research will undermine other programmes, including $\$ 3$ billion worth of scientific research each year.

The laboratories, which employ 30,000 people, conduct most of the basic physics research in the United States as well as important programmes in environmental science, biology and other disciplines.

A National Nuclear Security Administration will come into being next March if, as expected, President Bill Clinton signs a defence authorization act that legislates for its establishment, passed by both houses of Congress this month. The agency will be semi-autonomous within the Department of Energy (DoE).

The establish-

ment of the agency is supported by many researchers at the three huge weapons laboratories - Los Alamos and Sandia in New Mexico, and Lawrence Livermore in Cali- Under threat? Los Alamos fornia. They hope health research laboratory. it will free them

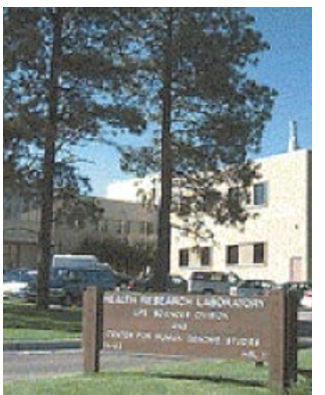

from some of the bureaucracy that has characterized their management by the DoE.

But scientists working on non-weapons programmes in these labs worry that support for their work will erode over time, as the laboratories focus on the new agency's mission of nuclear weapons research. Each of the three laboratories receives annual funding of around $\$ 1$ billion, of which onethird at Livermore and one-quarter at the two New Mexico labs is for non-weapons programmes.

Managers and scientists elsewhere in the department's huge network of laboratories fear that their needs have been overlooked in the reforms, which were rushed through Congress this summer in response to allegations of Chinese spying at Los Alamos.

In the short term, the non-weapons labs fear that support will be undermined for the work they do for the weapons programme. About one-third of the work of the Pacific Northwest National Laboratory (PNNL) in Washington state and the Oak Ridge laboratory in Tennessee serves missions that will be transferred to the new agency. But both laboratories will remain under the direct control of the DoE.

"We don't think that, for a change of this magnitude, this has been properly thought

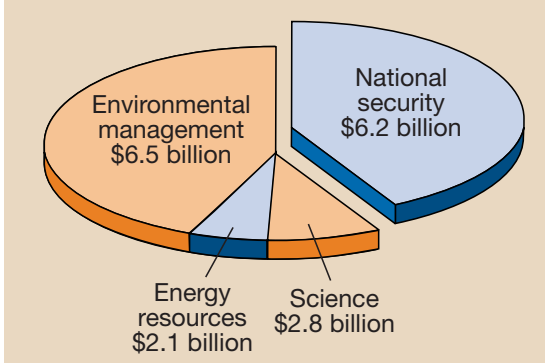

will be better placed to attack the rest of the department's budget. "It's going to make it easier for Congress to abolish the department," says Steve Dean of Fusion Power Associates, a fusion-research advocacy group, and a long-time observer of the department.

Representative William Thornberry (Republican, Texas) framed the reform legislation setting up the new agency along with Senator Pete Domenici (Republican, New Mexico). Thornberry admits that the interests of the nuclear weapons programme came first. "For me, the most important mission of the department is the maintenance of a safe and reliable stockpile of nuclear weapons," he says.

He adds that it was not feasible for the legislation to reform the rest of the department. Thornberry, and congressional staff involved in writing the legislation, say that scientific exchange should continue between the weapons and the non-weapons labs. But they say it is up to the Department of Energy to work out how this should be done, as it implements the law over the next few months.

Energy secretary Bill Richardson has opposed the reforms and called on Clinton to veto them. The president is unlikely to do so because of the margins by which the law passed. So the DoE is starting quiet preparations to implement the reforms and is said to have begun sounding out candidates to run the agency.

Environmentalists are perturbed by the autonomy to be granted to the agency. They sought to derail the agency proposal in Congress on the grounds that it would weaken environmental controls in the nuclear weapons complex. Backers of the reforms counter that the agency will have to adhere to existing environmental laws. Colin Macilwain With weapons research in the new
agency, the DoE's many enemies in Congress

\section{Allègre defends synchrotron plans}

\section{Paris}

Claude Allègre, France's science minister, has publicly outlined his reasons for scrapping plans for a French synchrotron, and instead joining British plans to build a similar machine.

Arguing that money spent on large, 'Big Science' facilities should be rerouted into research projects, Allègre said in a written statement last week that to do this France had to team up with other European countries to build such facilities.

But political opposition to his decision remains strong. At a speech to a committee of the Academy of Sciences, president
Jacques Chirac denounced Allègre's decision. "The Soleil project is one of the best scientific facilities that France can realize in the years to come with its scientific community for research and progress, notably in the sectors of health and industry," said Chirac.

The staff at the LURE synchrotron, at Orsay outside Paris, who have been refusing to switch on their facility's $800 \mathrm{MeV}$ and $1.85 \mathrm{GeV}$ machines for the last three weeks in protest, demonstrated last week at the regional council of the Ile-de-France, which lobbied the government to host the facility. They were backed by the general council 
$\checkmark$ of the department of Essone.

In his

statement, Allègre says that "to

preserve the possibility of realizing other, more

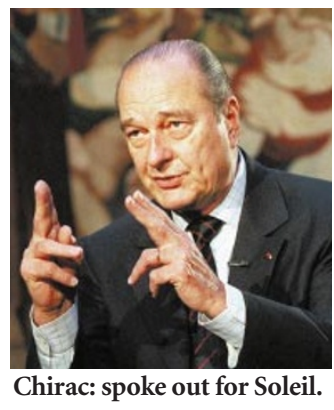

urgent,

projects, we could have simply decided not to finance the synchrotron project, seen as too expensive and not urgent. We did not do that. The strategy adopted was to preserve the interests of the French scientific community, in particular the users of synchrotron radiation, in searching for a European solution.

"Are we in the future going to be lacking synchrotron time? Nothing indicates that. Of course, certain administrators and some users of these machines say so, and without doubt believe it, but experience teaches us that in this domain it is difficult to plan ahead."

To boost research labs, emerging disciplines and the recruitment of young scientists, Allègre says he has decided to rebalance the budget by decreasing the funds spent on large facilities. To accomplish such a reduction, Allègre says his aim is to make any new, large facilities European.

The minister adds that he chose Diamond, the planned 3-GeV machine, because FF1.1 billion of the FF1.8 billion (US $\$ 286$ million) needed will be paid by the Wellcome Trust, whereas the French and British governments will each pay FF350 million.

Scientists at LURE challenge some of his figures, arguing, for example, that Allègre underestimates the X-ray needs of French researchers. In contrast to Allègre's statement that French machines are not "saturated", they argue that LURE accepts only 65 per cent of requests for beam-time.

The international synchrotron community has supported the protests, backing the claims of French scientists that they were largely ignored in the decision-making process. Among those behind LURE's cause are the British Nobel Prize winner Max Perutz and the directors of numerous European synchrotron facilities.

But France will only build Soleil if opposition emerges within Allègre's ruling Socialist party. Some members of the party have been critical, but prime minister Lionel Jospin has yet to make a statement on the matter. Heather McCabe

\section{cDNA sequence databank will safeguard research access}

\section{Phoenix, Arizona}

The US National Institutes of Health (NIH) is about to announce details of the creation of a repository for full-length human complementary DNAs (cDNAs), which will provide a source of both genetic sequences and clones for any researcher who requires them.

The Mammalian Gene Collection, which will eventually also include full-length mouse and rat cDNAs, is designed to bring together molecular data stored by individual researchers. The collection, which federal officials say has been allocated total funding of $\$ 10$ million, hopes to have its Internet website functioning next month.

Organizing efforts are being led by the collection's co-directors, Robert Strausberg, assistant to the director of the National Cancer Institute, and Elise Feingold of the National Human Genome Research Institute. Officials say that support for the collection is coming from 16 of the NIH's institutions and the National Library of Medicine.

"We are building this as a resource where anyone can get clones and all information will be available to anyone," said Strausberg. The public storage and availability of such data is being undertaken in part to combat some restrictive corporate efforts to withhold results for proprietary reasons. A full description of the Mammalian Gene Collection will appear in an article in Science.

The principal goal of the collection is to expand genetic storage from expressed sequence tags (ESTs) to full-length cDNA, said Strausberg, who revealed the plans for the repository last week at a meeting on microarrays sponsored by Nature Genetics.

More than a million ESTs are stored in GenBank, a repository operated by the National Center for Biotechnology Information. Some ESTs correspond with known genes, whereas others represent partially sequenced novel genes. Providing molecular biologists with a full cloned sequence will give researchers an expanded canvas of genetic material to work with, while ensuring wide access to the crucial information.

The ever-growing need for more molecular depth was evident at the meeting in Phoenix, where about 400 molecular biologists heard presentations on new techniques and discoveries. With microarray technology, researchers can profile the expression pattern of tens of thousands of genes in a single experiment by arraying DNA targets on glass slides or membranes and probing them with fluorescent or radioactively labelled cDNA.

As well as using microarray technology for fundamental discoveries, researchers are broadening applications into disease diagnosis and plant biology. The technology is being used to try to determine the molecular cause of diseases, helping to define new classifications of diseases and redirect treatments for some malignancies. Rex Dalton

\section{Fur flies over rare-species panel}

\section{Montreal}

Canadian biologists and environmental groups are angry at what they claim are continued efforts by provincial and federal governments to politicize the process by which species are added to the endangered list. In particular, they are worried at moves to give representatives from private corporations direct involvement in the process.

Earlier this year, more than 600 scientists wrote to the prime minister, Jean Chrétien, demanding that the rights to identify and list endangered species be given exclusively to scientists, and that politicians should not be allowed to override such decisions.

Christine Stewart, then Canada's environment minister, responded by adding eight more scientists as voting members to the Committee on the Status of Endangered Wildlife in Canada (COSEWIC), which identifies the species that should be on the list (Nature 398, 9 \& 358; 1999). The govern- ment had previously removed the voting rights of most non-governmental scientist members.

But a draft operating manual for the committee, leaked to The Globe and Mail newspaper in Toronto, shows that, for the first time, members of private corporations would be allowed to sit on the committee.

Committee member Gilles Seutin of McGill University says that many members are concerned that the government is trying to dilute its decisions. And David Schindler of the University of Alberta, who drafted the earlier letter to the prime minister, says there is no place for non-scientists, politicians or industry representatives on COSEWIC. Schindler cites the possibility of a biologist working for a forestry company that might have an interest in not seeing a particular bird placed on the list.

According to the newspaper report, the leaked document also says that COSEWIC 